\title{
Resistance of Aegilops, maize and wheat genotypes to Pseudomonas syringae pathovars atrofaciens and syringae
}

\author{
V Vassilev *, K Kolev, M Zaharieva, V Sevov \\ K Malkoff Institute for Plant Genetic Resources, 4122 Sadovo-Plovdiv, Bulgaria
}

(Received 7 October 1994; accepted 20 February 1995)

\begin{abstract}
Summary - The resistance of cereal genotypes to the artificial inoculation of Pseudomonas syringae pathovars atrofaciens (PSA) and syringae (PSS) at third leaf growth stage of development was investigated. The methods of pricking and injecting were used. The injection method produced symptoms similar to natural infection, at level of inoculum at least $10^{7} \mathrm{cfu} / \mathrm{ml}$. At this stage of cereal growth there was a high level of resistance to PSA and PSS. None of the Aegilops species showed the symptoms of susceptible genotypes. Only one Triticum genotype was susceptible to strains V28 and Y4895 of PSA and PSS, respectively, at the highest level of inoculum. The leaves of all Zea mays genotypes were susceptible to PSS A106 at $10^{\circ} \mathrm{cfu} / \mathrm{ml}$.
\end{abstract}

cereals / resistance / Pseudomonas syringae / atrofaciens / syringae

Résumé - Résistance des génotypes d'Aegilops, de maïs et de blé à Pseudomonas syringae pathovars (pvs) atrofaciens (PSA) et syringae (PSS). La résistance au PSA et au PSS des génotypes des céréales a été étudiée après inoculation par les méthodes de scarification et d'injection. La dernière méthode permet d'obtenir des symptômes de maladie similaires à ceux obtenus dans la nature au niveau d'inoculum de $10^{7} \mathrm{cfu} / \mathrm{ml}$ et plus. Les plantules au stade 3 feuilles ont montré un niveau élevé de résistance à PSA et PSS. Aucune espèce d'Aegilops n'a montré d'infection comme chez les génotypes sensibles. Un seul génotype de Triticum est sensible au plus haut niveau d'inoculation par PSA V28 et PSS Y4895. Les feuilles de tous les génotypes de maïs sont sensibles au PSS A106 à la concentration de $10^{9} \mathrm{cfu} / \mathrm{ml}$.

céréales / résistance / Pseudomonas syringae / pathovars atrofaciens, syringae

\section{INTRODUCTION}

Vassilev et al (1983) have previously reported resistance in the early growth stage of cereals to Pseudomonas syringae pathovar atrofaciens (PSA). Most of the studied species (barley, rye, triticale, and wheat) usually show resistant plant responses up to the stage of leaf-sheaths length- ening (Large, 1954). In our country, bacterial leaf blights occurred at this growth stage of plant development. Some were caused by PSA, others by $P$ syringae pathovar syringae (PSS) or both (Karov and Vassilev, 1990). Initial water-soaked spots about $1-3 \mathrm{~mm}$ in diameter expanded, became necrotic and progressed from gray or yellow-green to light-tan or white. The spots may

${ }^{*}$ Correspondence and reprints 
coalesce into irregular stripes or blotches in a short period of time (2-4 d). Entire leaves often became necrotic and died. Similar types of symptoms, especially at the later stages of bacterial infection, were sometimes mixed with lesions caused by frost or fungi. On leaves, the browned tissue resulting from bacterial infection was often confused with natural senescence. The losses caused by PSA and PSS have not been well assessed, because of the complex biotic and abiotic factors involved. Continuing earlier studies, we used artificial inoculation to investigate the plant resistance to PSA and PSS of some Aegilops $L$, Zea mays $L$, and Triticum $L$ genotypes at the third leaf stage of plant growth. The methods of pricking and injecting were used in a non-air-conditioned glasshouse.

\section{MATERIALS AND METHODS}

Six strains of PSA and PSS, ie two PSA, V1 and V28, two PSS, A106 and Y4895 isolated from wheat, and two PSS, $Y 3023$ and $Y 3080$ from Syringae vulgaris $L$ for which pathogenicity has been proved (Vassilev et al, 1991), were inoculated by pricking (Method 1) or injecting (Method 2) plants at the third leaf stage of growth. Bacteria were stored lyophilized and were grown for routine work on nutrient glycerine agar (NGA) (Rudolph et al, 1990).

Plants from the IPGR collection with a large genetic diversity were represented by 22 Aegilops $L$, maize and wheat genotypes, which were grown in pots (Vassilev, 1984) till the third leaf. We used 10 healthy plants for Method 1 and for each inoculum level in Method 2. The inoculated plants were incubated in a non air-conditioned glasshouse and kept in moist air by spraying with tap water. All experiments were performed 3 times.

\section{Method 1}

Each leaf was pricked at 3 sites with a fine needle contaminated with bacterial culture aged 24-48 h (Galachyan, 1941). Controls were pricked with a drop of sterile water. Responses were evaluated on days 7 , 14 and 28 after inoculation. A brown spot with a darkbrown margin and a yellow halo, which spread out further from the point of inoculation, was recorded as a susceptible response. No symptoms or a small brown spot restricted to $1 \mathrm{~mm}$ around the wound were scored as an immune or resistant response, respectively (Vassilev et al, 1991).

\section{Method 2}

Each pseudo-stem was injected in the middle using a $1 \mathrm{ml}$ syringe. Various inoculum doses $\left(10-10^{9} \mathrm{cfu} / \mathrm{ml}\right)$ of 24-48 $\mathrm{h}$ bacterial culture were adjusted at $610 \mathrm{~nm}$ of Specol 10 (Carl Zeiss) using a calibration curve of the PSA and PSS strains. The number of infectious particles forming colonies on a solid medium (cfu/ml) was determined by the method of serial dilution and plate-count technique (Meynell and Meynell, 1965). Controls were treated with sterile water. Plant responses were evaluated on days 7,14 and 28 after inoculation. Five grades were used (0-4): plants without symptoms (0); plants with local necrosis only on the site of injection (1); plants with a $1-3 \mathrm{~mm}$ restricted spot (2); plants with $3 \mathrm{~mm}$ lesions with yellow halo near of the place of inoculation (3); and (4) plants with spots scattered on the entire leaf blade (necrotic and later dry). The degree of infection has been calculated (Vassilev and Karov, 1986; Vassilev et al, 1990) and 5 groups of plant responses were described: $0.0-0.0$ immune (I); 0.1-37.5 resistant (R); 37.6-50.0 medium resistant (MR); 50.1-62.5 medium susceptible (MS); and $62.6-100.0$ susceptible (S)

\section{RESULTS AND DISCUSSION}

The 6 selected PSA and PSS strains isolated from wheat and lilac used in this study were recovered from lyophilized cultures on NGA. Bacteria were typical for PSA and PSS. They were also chosen for their virulent properties (results not presented). These 2 pathovars caused diseases on cereals (PSA) and many other species (PSS). On the cereals, PSA was usually more damaging to plants than PSS at lower inoculum levels and during the whole vegetation period (unpublished results). Otta (1974) reported no differences between PSS and PSA. Our earlier results (Vassilev et al, 1991) obtained in the seedling bioassay and ear spraying, distinguished PSA from PSS. It was hard to differentiate between symptoms caused by PSA and PSS in the late stage of development of cereal plants until the milk ripe stage, in which basal glume rot caused by PSA was originally described on the head of wheat at the base of glumes as a duli brownishblack area (McCulloch, 1920). Using only PSA strains caused typical symptoms on the ear and made it possible to search the plant responses at every stage of cereal development. In comparison, PSS never caused typical basal glume rot on the head of cereals (Vassilev and Karov, 1982; Toben et al, 1989; Vassilev et al, 1991).

In our trials, only the injection method gave clear symptoms above $10^{7} \mathrm{cfu} / \mathrm{ml}$. The controls were not affected. We present the highest plant responses at the highest inoculum levels for some representative genotypes from the experiments done 3 times for different time periods (tables I, II and III). At the third leaf stage of cereal growth, 
Table I. Responses of some Aegilops genotypes to artificial inoculation with strains of PSA and PSS.

\begin{tabular}{|c|c|c|c|c|c|c|c|}
\hline \multirow[t]{2}{*}{ Strain } & \multirow[t]{2}{*}{ Concentration $(c f u / m l)^{\text {a }}$} & \multicolumn{6}{|c|}{ Genotype b } \\
\hline & & $28 / 20$ & 87110003 & $36 / 17$ & 87110009 & 87110021 & $39 / 18$ \\
\hline PSA V1 & $\begin{array}{l}10^{7} \\
10^{9}\end{array}$ & $\begin{array}{l}1 \\
1\end{array}$ & I & $\begin{array}{l}1 \\
1\end{array}$ & $\begin{array}{l}\text { I } \\
\text { MS }\end{array}$ & $\begin{array}{l}\text { MS } \\
\text { MS }\end{array}$ & I \\
\hline PSA V28 & $\begin{array}{l}10^{7} \\
10^{9}\end{array}$ & $\begin{array}{l}1 \\
1\end{array}$ & $\begin{array}{l}1 \\
1\end{array}$ & 1 & I & $\begin{array}{l}\text { MS } \\
\text { MS }\end{array}$ & $\begin{array}{l}\text { MS } \\
\text { MS }\end{array}$ \\
\hline PSS A106 & $\begin{array}{l}10^{7} \\
10^{9}\end{array}$ & I & $\begin{array}{l}1 \\
R\end{array}$ & $\begin{array}{l}\text { MS } \\
\text { MS }\end{array}$ & $\begin{array}{l}\text { MS } \\
\text { MS }\end{array}$ & $\begin{array}{l}\text { MS } \\
\text { MS }\end{array}$ & I \\
\hline PSS Y3023 & $\begin{array}{l}10^{7} \\
10^{9}\end{array}$ & $\begin{array}{l}1 \\
1\end{array}$ & $\begin{array}{l}1 \\
1\end{array}$ & 1 & $\begin{array}{l}1 \\
1\end{array}$ & I & 1 \\
\hline PSS Y3080 & $\begin{array}{c}10^{7} \\
10^{9}\end{array}$ & I & $\begin{array}{l}1 \\
1\end{array}$ & 1 & MS & $\mathrm{I}_{\mathrm{MS}}$ & 1 \\
\hline PSS Y4895 & $\begin{array}{l}10^{7} \\
10^{9}\end{array}$ & 1 & 1 & $\begin{array}{l}\text { MS } \\
\text { MS }\end{array}$ & 1 & $\begin{array}{l}\text { I } \\
\text { MS }\end{array}$ & $\begin{array}{l}\text { MS } \\
\text { MS }\end{array}$ \\
\hline
\end{tabular}

a Concentration of bacterial suspension (cfu/ml); b I: immune; R: resistant; and MS: medium susceptible.

Table II. Responses of some maize genotypes to artificial inoculation with strains of PSA and PSS.

\begin{tabular}{|c|c|c|c|c|}
\hline \multirow[t]{2}{*}{ Strain } & \multirow[t]{2}{*}{ Concentration $(c f u / m l)^{a}$} & \multicolumn{3}{|c|}{ Genotype } \\
\hline & & $87 B M 57$ & 3163 & 2198 \\
\hline PSA V1 & $\begin{array}{l}10^{7} \\
10^{9}\end{array}$ & $\begin{array}{l}\text { MS } \\
\text { MS }\end{array}$ & $\begin{array}{l}\text { MS } \\
\text { MS }\end{array}$ & $\begin{array}{l}\text { MS } \\
\text { MS }\end{array}$ \\
\hline PSA V28 & $\begin{array}{l}10^{7} \\
10^{9}\end{array}$ & $\begin{array}{l}\text { MS } \\
\text { S }\end{array}$ & $\begin{array}{l}\text { MS } \\
\text { MS }\end{array}$ & $\begin{array}{l}\text { MS } \\
\text { MS }\end{array}$ \\
\hline PSS A106 & $\begin{array}{l}10^{7} \\
10^{9}\end{array}$ & $\begin{array}{l}S \\
S\end{array}$ & $\begin{array}{l}\text { MS } \\
\text { S }\end{array}$ & $\begin{array}{l}\text { MS } \\
\text { S }\end{array}$ \\
\hline PSS Y3023 & $\begin{array}{l}10^{7} \\
10^{9}\end{array}$ & $\begin{array}{l}\text { MS } \\
\text { MS }\end{array}$ & $\begin{array}{l}\text { I } \\
\text { MS }\end{array}$ & $\begin{array}{l}\text { I } \\
\text { MS }\end{array}$ \\
\hline PSS Y3080 & $\begin{array}{l}10^{7} \\
10^{9}\end{array}$ & $\begin{array}{l}\text { MS } \\
\text { MS }\end{array}$ & $\begin{array}{l}\text { I } \\
\text { MS }\end{array}$ & $\begin{array}{l}1 \\
1\end{array}$ \\
\hline PSS Y4895 & $\begin{array}{l}10^{7} \\
10^{9}\end{array}$ & $\begin{array}{l}\text { MS } \\
\text { MS }\end{array}$ & 1 & $\begin{array}{l}1 \\
1\end{array}$ \\
\hline
\end{tabular}

a Concentration of bacterial suspension (cfu/ml); b I: immune; MS: medium susceptible; and S: susceptible.

there was a high level of resistance to PSA and PSS. None of the Aegilops species showed the symptoms of susceptible genotypes. One Triticum genotype was susceptible to strains V28 and Y4895 of PSA and PSS, respectively, at the highest level of inoculum. In this case, initial water-soaked spots, like the natural ones, about
1-3 $\mathrm{mm}$ in diameter were observed. They expanded, became necrotic and progressed from gray or yellow-green to light-tan or white. The spots coalesced into irregular stripes or blotches in short period of time (2-4 d). Very often, entire leaves became necrotic and died. On leaves, the browned tissue resulting from artificial bacterial 
Table III. Responses of some wheat genotypes to artificial inoculation with strains of PSA and PSS.

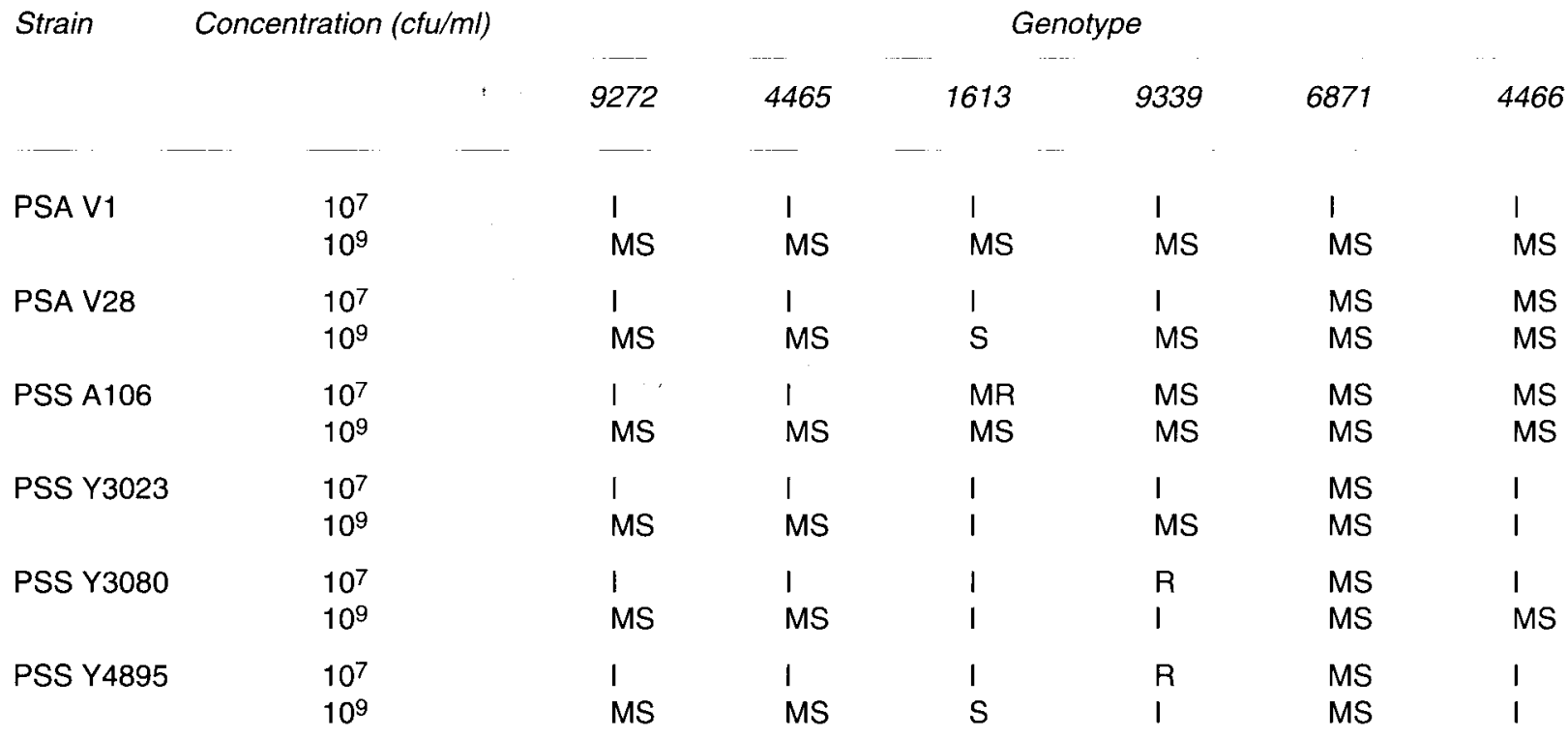

a Concentration of bacterial suspension (cfu/ml); ${ }^{\mathrm{b}} \mathrm{I}$ : immune; R: resistant; MR: medium resistant; MS: medium susceptible; and S: susceptible.

infection was very soon indistinguishable from natural senescence. The leaves of all $Z$ mays genotypes were susceptible to PSS A106 at the $10^{9} \mathrm{cfu} / \mathrm{ml}$. Symptoms were typical (round, white to light-tan spots, usually up to $5 \mathrm{~mm}$ in diameter). Sometimes elongated tan spots and stripes resembled Setosphaeria turcica (Northern leaf blight) symptoms on the leaves of $Z$ mays genotypes which are susceptible to bacterial blights. Isolations from the lesions confirmed the identity of the artificially inoculated bacteria (unpublished results).

The injection method always gave more readable and constant responses in a non-air-conditioned glasshouse. The pricking method was rapid and usable for pathogenicity test (Galachyan, 1941; Wilkie, 1973), but it was not suitable for estimation of the plant resistance, especially when it was difficult to ensure very high humidity (relative humidity near $100 \%$ ). It was thus not possible to measure a real inoculum level (Vassilev et al, 1990). Such a measurement is requisite for exact assessment of quantitative resistance of cereals to facultative pathogens at various growth stages of plant development.

\section{ACKNOWLEDGMENTS}

The authors are very grateful to $\mathrm{J}$ Young, Auckland, New Zealand, and K Rudolph, Göttingen, Germany for their kindness in providing us with the original strains: A106 from M Arsenievic, Yugoslavia; Y3023 from KA Sabet, UK, Y3080 from WH Burkholder, USA; Y4895 from JD Otta, USA.

\section{REFERENCES}

Galachyan RM (1941) Testing the pathogenicity of strains of Bacterium atrofaciens under laboratory conditions. Rep WASHNIL 11, 40-43

Karov S, Vassilev V (1990) Bacterial diseases of Graminae in Bulgaria. In: Proc 7th Intern Conf Plant Pathog Bacteria, Akadémiai Kiadó, Budapest, Hungary, part A, 311-316

Large EC (1954) Growth stages in cereals - illustration of the Feekes scale. Plant Patho/ 3, 128-129

McCulloch L (1920) Basal glumerot of wheat. J Agric Res 28, 543-551

Meynell G, Meynell E (1965) Theory and Practice in Experimental Bacteriology. Univ Press, Cambridge, UK

Otta JD (1974) Pseudomonas syringae incites a leaf necrosis on spring and winter wheats in South Dakota. Plant Dis Reptr 58, 1061-1064

Rudolph K, Roy MA, Sasser M et al (1990) In: Methods in Phytobacteriology (Z Klement, $\mathrm{K}$ Rudolph, DC Sands, eds) AK, Budapest, Hungary, 45-86

Toben H, Mavridis A, Rudolph K (1989) Basal glume rot ( $P$ syringae $\mathrm{pv}$ atrofaciens) on wheat and barley in FRG and resistance screening of wheat. Bull OEPP/EPPO Bull 19, 119-125 
Vassilev V (1984) Studies on basal glume rot of cereals and wheat resistance to it. PhD dissertation, Univ Agric, Plovdiv, Bulgaria, 33-44

Vassilev V, Karov S (1982) External symptoms of wheat basal glume rot in Bulgaria. Plant Sci 19, 99-106

Vassilev V, Karov S (1986) Methods of artificial inoculation and evaluation of wheat resistance to $P$ syringae pv atrofaciens. Soil Sci Agrochem Plant Protect 1, 92-99

Vassilev V, Karov S, Matzov B, Perfanov K (1983) Responses of cereals artificially inoculated with $P$ syringae pv atrofaciens in different stages of development. In: Proc 2nd Nat Symp Immun Plants, VSI, Plovdiv, Bulgaria, 205-213
Vassilev V, Milanova M, Karov S (1990) Methods of inoculation and evaluation of quantitative wheat resistance to facultative pathogenic microorganisms in the ear. In: Proc Intern Symp Wheat Breed Prospects and Future Approaches. Univ Press, Varna, Bulgaria, 327-330

Vassilev V, von Kietzell J, Toben H, Mavridis A, Rudolph K (1991) Studies on wheat Pseudomonas syringae interactions. In: Proc 4th Intern Work Group Pseudomonas syringae Pathovars, Stamperia Granducale. Florence, Italy, 109-116

Wilkie JP (1973) Basal glume rot of wheat in New Zealand. N Z J Agric Res 16, 155-160 